\title{
A Survey of Civic Engagement Tools and Capabilities of City and County Government Web Sites
}

\author{
Samuel C Mwangi ${ }^{1 *}$ \\ (iD) 0000-0001-5044-3430 \\ ${ }^{1}$ Kansas State University, Manhattan, KS, USA \\ *Corresponding author: scmwangi@ksu.edu
}

Citation: Mwangi, S. C. (2021). A Survey of Civic Engagement Tools and Capabilities of City and County Government Web Sites. Online Journal of Communication and Media Technologies, 11(4), e202123. https://doi.org/10.30935/ojcmt/11255

ARTICLE INFO

Received: 29 Jul 2021

Accepted: 12 Sep 2021

\begin{abstract}
Innovations in web technology have the potential to help city and county governments improve their delivery of services and engage local communities in governance. Using civic engagement theories and best practices of online civic engagement, this research project audits 100 local government sites for their civic engagement capabilities. Results indicate that most cities and county governments place a heavy emphasis on using their websites to streamline delivery of services and little effort in promoting citizen participation and democracy. Building on Musso's model that distinguishes between managerial versus democratic models of engagement for government websites, we suggest a civic engagement model for local governments that goes beyond service delivery and emphasizes the participation of citizens in the local democratic process.
\end{abstract}

Keywords: mediated communication, civic engagement, e-government, local government, democracy

\section{INTRODUCTION}

Researchers have discussed the potential of using new media technologies to promote political participation and civic engagement (Dwivedi et al., 2017; Mwangi, 2012; Nip, 2006; Rosenberry, 2005; Schultz, 1999). Some scholars have paid special attention to the use of technology by local governments to enhance service delivery and citizen participation at the local level (Munro et al., 2000). Along that line, CivicPlus, a company based in Kansas, USA, has established itself as a leading developer of websites for city and county governments to promote community engagement. Using what they call a dynamic communication model (as opposed to a static, one-way communication model), CivicPlus provides integrated websites centered around a citizen-focused communication model for municipalities to engage citizens in their communities by making it easier for them to find information online, access services online, facilitate transactions, facilitate feedback and two-way communication, and enable citizen participation in decision- making. To date, they have helped design websites for hundreds of municipalities around the USA.

This is part of an emerging trend where local governments are establishing online presence to engage and serve their citizens. The International City/County Management Association surveyed all city governments in the USA with a population of 10,000 or more and found that 97 percent had a website and that their primary reason for establishing an online presence was to streamline local government services and improve citizen participation in government. But there has been little research conducted on civic engagement and government websites and especially how local governments are using communication technology to involve citizens in local democracies (Coleman \& Gotze, 2003). That is the focus of this paper. This research examines the technological tools deployed on municipal governments websites for civic engagement. Further, the research seeks to find out the model of civic engagement predominant on such sites using Munro's model that distinguishes between managerial versus democratic models of engagement for government websites

Copyright (c) 2021 by authors; licensee OJCMT. This article is an open access article distributed under the terms and conditions of the Creative Commons Attribution License (http://creativecommons.org/licenses/by/4.0/). 
(Munro et al., 2000) and Lee's stage-based model that views e-government as the last stage in an evolutionary process of using ICTs to engage citizens (Lee, 2010).

\section{LITERATURE REVIEW}

Civic engagement is defined as a sense of responsibility through which citizens act as agents of positive social change for a more democratic world (Mwangi et al., 2014; Coalition for Civic Engagement and Leadership, 2004). Common concepts used in defining civic engagement include knowledge of and discussion of public affairs (Jennings \& Zeitner, 2003; Levine, 2007; Mossberger et al., 2008, p. 48; Norris 2001, p. 219), community participation (Paek et al., 2005), Community involvement (Jeffres et al., 2002; Verba et al., 1995), political behaviors (Moy et al., 2005) or public involvement (Clift, 2004; Margolis \& Resnick, 2000). These concepts emphasize the idea of agency and participation in community affairs and in public and civic action through individual or group actions.

According to the Center for Information and Research on Civic Learning and Engagement, common indicators of civic engagement include: voting in national elections, joining a political party, being a candidate for local office, and civic activism, such as writing letters to a newspaper about social or political concerns, collecting signatures for a petition, collecting money for a social cause and boycotting products or services because of social concerns (CIRCLE, 2003). For citizens to be engaged in civic life, they must be equipped with certain skills such as knowledge and understanding of community issues, values that support a civic culture, a willingness to act to advance the public good and the skills and ability to imagine a better society and direct social change (Carpini, 2000; Pratte, 1988).

Local government websites provide a new venue for the presentation of information on government policies, programs and processes. Armed with such information, citizens become better equipped to engage public officials in discussions, and to become involved and participate in the affairs of the local governments. This definition of civic engagement goes beyond the mere provision of services. Civic engagement is also defined as membership in collective activities for establishment and nourishment of the community through active citizenry (Shah et al., 2001). This study adopted Khang and Gearhart's two types of civic engagement found on city websites namely civic involvement in city issues (e.g., participation in city improvement and city projects), and political behaviors (e.g., participation in voting, petition drives, and hearings).

Scholars have identified three dimensions of civic engagement that websites built for civic engagement must provide namely, connecting to the community; engaging individuals as citizens; and helping public deliberation in search of solutions (Nip, 2006). Shah et al. (2005) found that online information seeking as well as civic messaging strongly influenced citizens' civic participation than uses of traditional print and broadcast media or person-to-person communication, especially among young people. Bimber $(1999,2000)$ notes that this is changing to embrace all age groups as the internet gains more acceptance across age groups.

The potential of the internet to enhance communication and political participation appears to be much higher for certain dimensions of participation such as participating in opinion polls and surveys as well as contacting elected representatives and is equally powerful in enhancing the political participation of geographically dispersed citizens, those who have similar interests, as well as those with limited mobility (Rabya, 2005). Others note the internet's capacity to lower entry barriers for disadvantaged groups that are now able to organize and create networks and voice their concerns (Gross, 2001; Jones, 1998; Jordan, 2002; Lin \& Dutton, 2003). While some scholars see new media as having the potential to enhance democracy by creating a cyber commons (Blumler \& Gurevitch, 2001; Papacharissi, 2004; Shah et al., 2005; Tambini, 1999), others point out that the internet can also be used to build social capital by taking advantage of information distribution networks to connect communicators (Kavanaugh et al., 2001).

The introduction of social media and its rising dominance as a tool of communication among citizens created new expectations that its interactive features would boost citizen engagement efforts by local governments. This expectation has resulted in various research projects over the last decade with mixed results (Dwivedi et al., 2013). Some studies have found that social media can have a significant and positive impact in the adoption of e-government and in promoting civic engagement (Cottrell and King; Kaigo and Okura). Other studies have found that citizens have a higher preference of social media over other online tools used by local governments in engaging citizens (Alarabiat et al; Boudjelida et al., in a wide-raging review 
of research papers that have been published on social media and e-governments, Dwivedi, 2013) found that the most widely explored themes in these studies included "electronic participation", "engagement", transparency", communication/interaction, "trust" and "collaboration" clearly indicating the growing view that social media has the potential to promote engagement and democratic participation if deployed for those purposes. But a study that examined how Swedish municipalities were using social media found that they used social media to help citizens procure traditional services through their Web sites (Liden \& Larsson, 2016).

These studies seem to suggest that despite the rich interactive features of social media, cities were largely deploying them on their websites to ease the process of accessing traditional services. But as pointed out in a recent study that examined new forms of internet-based communications in UK local governance, Web 2.0 platforms such as Facebook and Twitter afford new opportunities for interaction that could bridge the divide between residents as consumers of local services and residents as citizens or democratic actors (Ellison \& Hardey, 2014).

Scholars have found that internet users have a high level of engagement in political activities and increased involvement in voluntary organizations (Hill \& Hughes, 1998; Johnson \& Kaye, 1998, 2000; Pinkleton \& Austin, 1998; Wellman et al., 2001), and internet access has been shown to be a predictor of civic participation (DuttaBergman, 2005; Shah et al., 2005). People who use the internet to gather information and exchange ideas tend to be more socially and politically engaged (Hasse et al., 2002; Jennings \& Zeitner, 2003; Shah et al., 2001a) but scholars have also noted that such positive civic engagement through websites is dependent on other variables such as ease of use, usefulness, and enjoyment (McMillan et al., 2003; Tambini, 1999; Van der Heijden, 2003). Carpini (2000) has noted that the internet is equally useful for political elites such as candidates and office holders for offering them opportunities to create new networks, ease organizational communication, target particular audiences and tailor messages. While there is scant research on civic websites, internet researchers have distinguished between the various types of interactivity common on websites: interpersonal interactivity allows users to interact with other users through message boards, forums, emails and instant messages; content interaction allows users interaction with editorial content (Bucy, 2004; Nielsen, 2005).

Seeking to take advantage of the foregoing technological benefits and trends, the rising number of local government websites is geared towards a more efficient service delivery, easy access to local government services and increased emphasis on transparency that gained a new momentum after the election of Barack Obama who campaigned on a platform of increased transparency and access to government information (Jaeger \& Bertot, 2010). On his first day in office, Obama issued a Memorandum on Transparency and Open Government that set the framework for developing a system of transparency, public participation, and collaboration (McDermott, 2010). Research has highlighted the potential contribution of using information technology to enhance interactivity, transparency, accountability and openness of public sector entities. Using ICTs to promote transparency and the engagement of citizens is seen as a way of improving citizens' trust in government. A study of e-governments in the European Union found that most local governments in Europe were using ICTs to enhance transparency but the idea of using such technology to promote public dialogue and e-participation was still in its infancy (Bonson et al., 2012). A study of the 75 largest cities in the USA found an exponential increase in the number of municipal websites that had adopted social networks had increased from $250 \%$ to $600 \%$ over a two-year period (Mossberger \& Wu, 2012). Cities have also embraced the use of open data portals but at a slower rate. Open data portals allow users to access city data on crime, budgets, building permits, vacant land, and many other issues. The study found some cities were organizing competitions for the development of applications (apps) for other innovative uses of data.

ICTs have also introduced the idea of citizen co-production where citizens perform the role of partner rather than customer in the delivery of public services, especially given the many avenues for collaboration made possible by information technology that empowers the public to play a more active role in the functioning of their government (Linders, 2012).

Lee (2010) attempted to develop a stage-based theoretical framework to explain the various models of egovernment and argued that these could be classified in five metaphorical stages: presenting, assimilating, reforming, morphing, and e-governance all of which can be housed under the two themes of citizen/service and operation/technology. They included concepts such as information, interaction, integration, transaction, 
streamlining, participation, transformation, involvement and process management. The proposed metaphorical stages are a road map for the development of e-government. The development of digital democracy is seen as the last and long-term stage in this process and according to the United Nations, is focused on citizen's participation as a dimension that is separate from the service operations or technology aspects of e-government. E-democracy is seen as a long-term goal of e-government and is promoted through tools that promote citizen involvement and participation such as online polling, voting and surveys.

Creating a digital tool for civic engagement, as CivicPlus local government websites have sought to do, fits well within the ambit of the communication infrastructure theory that differentiates local communities depending on whether they have a communication infrastructure that can be activated to enable community action for a purpose (Kim \& Ball-Rokeach, 2006; Mwangi et al., 2013). Such an infrastructure consists of a neighborhood where citizens, grassroots organizations and the media disseminate stories that capture everyday conversations. The theory teases out three important community "story tellers" that serve as agents of civic engagement. The first is the local media which fosters a sense of belonging and civic participation (McLeod et al., 1996; Paek et al., 2005). The second form of storytelling that contributes to civic engagement occurs through community organizations where citizens engage common issues and leverage their capacities to tackle those issues as a community engaged in civic action (Putnman, 2000; Verba et al., 1995). The third form of storytelling occurs within individual networks that form between friends, family and within neighborhoods. Scholars argue that the act of exchanging stories within such networks positively impacts civic engagement (Kim et al., 2002; Kim \& Ball-Rokeach, 2006; McLeod et al., 1999). City government websites often feature these communication networks to make it easier for citizens to engage in their communities.

In a study of 250 local government websites, Moore developed a theoretical framework that distinguished between managerial versus democratic models of engagement for government websites. A managerial model focused on streamlining service delivery and made it easy for citizens to access services and transact business with the city using technology. On the other hand, the democratic model emphasizes the civic elements of engagement for democratic participation. Therefore, the managerial model of engagement emphasizes the production of outputs while the democratic model emphasizes the process of government decision making. The tools of engagement deployed on municipal sites are therefore geared to optimize the model of engagement chosen by particular local governments (Musso et al., 2001).

This study sought to answer three research questions:

(1) What are the tools for civic engagement available on municipal websites?

(2) How are these tools distributed on municipal websites?

(3) What model of civic engagement is emphasized on municipal websites?

\section{METHODOLOGY}

This study adopted Khang and Gearhart's two types of civic engagement found on city websites namely civic involvement in city issues (e.g., participation in city improvement and city projects), and political behaviors (e.g., participation in voting, petition drives, and hearings).

A list of websites created by Civicplus was entered into a spreadsheet to generate random numbers using Excel's Rand function. The list was then sorted using the order of corresponding random numbers to select the first 100 sites on the list. Inferences drawn from simple random sampling are generalizable (Krippendorf, 1980).

Inspired by literature on civic engagement as well as best practices for developing online tools for civic engagement, the study developed a list of online civic engagement tools expected to be present on websites developed for civic engagement. The research audited 100 sites selected through simple random sampling for the presence of such tools. Entire websites were examined through content analysis to identify the engagement tools present.

Content analysis is "a research technique for the objective, systematic, and quantitative description of the manifest content of communication" (Berelson, 1952, p. 18). Content analysis content analysis is ideal for a descriptive study-- such as the present one-- which seeks to describe identify and describe engagement tools on county government websites (Krippendorf, 1980; Wimmer \& Dominick 1997) 
To answer the third question, this study adopted Musso's framework of a managerial versus democratic model to assess whether the sites emphasis lay on outputs (enhanced service delivery) or citizen participation and involvement in the process of policy formulation and decision-making.

After IRB approval, two coders coded a sample of 10 websites. Intercoder reliability was calculated using Scott's pi index and yielded an agreement of .85. The researcher coded the rest of the websites.

\section{RESULTS AND DISCUSSION}

Local governments are the grassroots organizations closest to citizens and are therefore uniquely placed to engage citizens and promote their participation in the democratic process. This exploratory research sought to audit local government websites to identify the tools for civic engagement present on such sites. One hundred websites were randomly selected and analyzed using a rubric developed from the literature. Each of these sites were designed by Civicplus, a company whose stated mission is to design local government websites for civic engagement.

RQ 1. What are the tools for civic engagement available on municipal websites?

The websites appeared primarily designed to streamline service delivery and there was a heavy emphasis on transactional components such as paying utility bills and taxes, applying for a permit, renewing vehicle registration, accessing parks and recreation services, and waste management among other services. But many sites went beyond the service component and attempted to engage their citizens in city governance and in the democratic process. Tools available for civic engagement included: Social media for communication between citizens and city officials, language choice for those who are not fluent in English, polls and surveys, discussion forums, mapping tools for data visualization, databases for documents, space for community groups, civic initiatives such as community service opportunities or signing petitions, and information for knowledge and involvement on events such as city meetings. This finding appears to confirm Lee's stage based model of e-government that evolves from presenting information, assimilating, reforming, morphing and finally e-governance as the ultimate stage of evolution. That means most municipal websites were created to make it easier for citizens to access municipal services. But once that mission has been accomplished, city governments are slowly rolling out other tools beyond the service goals to get citizens involved in their local governments. While most of the features identified were part of the ideal civic engagement website in the literature, there is a gap that still exists. For example, none of the 100 sites audited had a dedicated online workspace for city officials and citizens to work together on city plans. Thus, while literature suggests that ICTs have introduced the idea of citizen co-production where citizens perform the role of partner rather than customer in the delivery of public services, none of the audited sites had embraced that model. Literature also suggested the use of games to generate interest and engagement with city issues but none of the sites had such a feature.

RQ 2. How are these tools distributed on municipal websites?

As indicated in Table 1, almost all the sites (98\%) used their websites to provide information for their citizens' knowledge and involvement. Such information was often about meetings and events. They also provided video or live streaming for those who wanted to watch the meetings. This is a critical service because information is at the heart of civic engagement and without information, citizens will not be able to participate in city issues or in political behaviors such as voting or petition drives.

$86 \%$ of websites had databases of important city documents such as budgets and city policies. Such use of city websites to provide citizens with critical information fits in well with the communication infrastructure theory that argues such an infrastructure and information are important in enabling community conversations and community action.

Social media played a critical role in connecting citizens and city officials and this interaction was supported on $75 \%$ of the site. Social media were also the tools of choice when it came to citizen interactions and discussions and $54 \%$ of sites allowed such grassroots discussions to happen. This is in line with the communication infrastructure theory where the story telling that contributes to civic engagement occurs through community organizations and infrastructures where citizens engage common issues and leverage their capacities to tackle those issues as a community engaged in civic action. 
Table 1. Distribution of engagement tools across the web sites

\begin{tabular}{lc}
\hline Tools for civic engagement on municipal websites & $\begin{array}{c}\text { Percentage of websites } \\
\text { providing capability }\end{array}$ \\
\hline Workspace for city and citizens to work together on city plans & $0 \%$ \\
Discussion forum & $1 \%$ \\
Games to generate interest & $0 \%$ \\
Surveys and polls & $20 \%$ \\
Social media for communication between citizens and city officials & $75 \%$ \\
Mapping capabilities for data visualization & $63 \%$ \\
Database of important documents such as budgets and city & $86 \%$ \\
Provide information for knowledge and involvement (meetings, events, video, live streaming) & $98 \%$ \\
Citizen interaction, facebook and twitter & $54 \%$ \\
Enable other civic initiatives (signing petitions, making donations, community service & $41 \%$ \\
opportunities) & $11 \%$ \\
Space for community groups & $0 \%$ \\
Information on technology centers for those without computers & $15 \%$ \\
Language choice &
\end{tabular}

RQ 3. What model of civic engagement is emphasized on municipal websites?

One of the seminal scholarly work to attempt to conceptualize community involvement was Arnstein (1969) which depicted citizen participation as a staged process where power is shared differently. Using the metaphorical "rungs on a ladder", she sketched out eight levels of participation, namely: citizen control, delegated power, partnership, placation, consultation, informing, therapy, manipulation. These rungs depict levels of citizen power with the bottom two non-participative rungs amounting to no power transfer to the citizens. Wild and Marshall have argued for a conceptualization that extends beyond Arnstein's levels of participation. They argue that we need to consider three other levels of participation, namely: the scope of community involvement, the methods of decision making structures being employed in the process, and to whom power is being devolved (Wild \& Marshall, 1999).

McDonald et al. (2016) argues that new media technologies have reconfigured the structures and locations of communities and that public administration needs to engage in critical reflections about engagement practices in the face of digital experiences of place and disaggregated models of the social.

A recent study sought to establish how different departments in a U.S municipal government conceptualized community engagement beyond service delivery and democracy and identified daily challenges that impacted engagement efforts between municipal governments and residents (Corbett \& Dantec, 2018).

Hand and Ching (2014) found that local governments that had adopted social media platforms that were built to facilitate the many-to-many engagement models continued to use such platforms using a speakingfrom power model on platforms that were otherwise designed to encourage citizens to speak to power.

$100 \%$ of the sites audited in the present research had tools that streamlined transactions and services delivery. Indeed, this appeared to be the fundamental purpose of creating the websites whose emphasis was what Musso calls a managerial model of engagement. This is seen as different from the democratic model whose emphasis is the participation of citizens in the democratic process. While Musso treats these models as separate Lee sees them as evolutionary with the managerial model eventually evolving to a democratic model of e-governance. There is merit in both positions. The Musso model is simply an acknowledgement that one of the primary functions of municipal governments is to provide services and citizens as taxpayers expect efficient services from their local governments. The model bets on efficiency to win the hearts and minds of voters. The Lee evolutionary model acknowledges the progressive needs for citizens to be involved in governance and decision making once their basic service needs have been met. This paper argues that local governments ought to combine both the managerial and the democratic models of engagement instead of picking one over the other. It has been over a decade since local governments embraced ICTs to help fulfill their missions. Technology has since evolved and there are tools in the market that can effectively enhance both service delivery as well as citizen engagement in the democratic process. It should not be a choice of one model over the other. Rather using the communication infrastructure that is municipal websites for twin engagement at the service as well as governance levels enhances both service and governance based on a 
process of mutual reinforcement: citizens participate in deciding the types of services they want from the city and how they want to access them. In turn their participation in such a process engenders a culture of democracy that is nurtured through tackling basic as well as complicated issues. Embracing the communication infrastructure model can help bridge the gap between Lee's evolutionary model and Musso's service versus democratic model. Every community requires an infrastructure that can be activated by citizens to tell their stories, engage issues and leverage their collective abilities to address such issues. The presence of such an infrastructure is not an evolutionary process but is at the heart of what it means to be a community. The earlier two models do not place a heavy emphasis on communication or the creation of community. The computer-mediated communication afforded by local government websites prioritizes communication as a key component in enhancing citizen participation in the democratic process and in determining the destiny and services they receive form their local governments.

\section{LIMITATIONS AND FUTURE RESEARCH}

This research sought to identify the civic engagement tools and capabilities present on city government websites. Given the growing capabilities of information communication technologies to enhance service delivery and governance, this research wanted to find out how local government entities are using such technologies to engage citizens. The study found that all the 100 sites audited were using technology to streamline their service delivery. The study also found that there is a gradual and sporadic attempt by municipal governments to roll out tools that help engage citizens at the governance level.

A future study could survey cities to try and identify the challenges associated with engaging citizens in the democratic process using technology. It is possible that the adoption of such a model has been slow due to limited manpower and capacity to deal with a deluge of mediated communication.

Another study could look at the depth and intensity of engagement that is taking place through ICTs to find out if there is sustained engagement and deliberation of public issues taking place using the tools deployed by city governments.

Funding: Author received no financial support for the research and/or authorship of this article.

Declaration of interest: Author declares no competing interest.

Data availability: Data generated or analysed during this study are available from the author on request.

\section{REFERENCES}

Arnstein, S. R. (1969). A ladder of citizen participation. Journal of the American Institute of planners, 35(4), $216-$ 224. https://doi.org/10.1080/01944366908977225

Bennett, W. L. (2000). Introduction: Communication and civic engagement in comparative perspective. Political Communication, 17, 307-312. https://doi.org/10.1080/10584600050178889

Berelson, B. (1952). Content analysis in communication research. Free Press.

Bertot, J. C., Jaeger, P. T., \& Grimes, J. M. (2010). Using ICTs to create a culture of transparency: E-government and social media as openness and anti-corruption tools for societies. Government Information Quarterly, 27(3), 264-271. https://doi.org/10.1016/j.giq.2010.03.001

Bertot, J. C., Jaeger, P. T., \& Hansen, D. (2012). The impact of polices on government social media usage: Issues, challenges, and recommendations. Government Information Quarterly, 29(1), 30-40. https://doi.org/10.1016/j.giq.2011.04.004

Bimber, B. (1998). The Internet and political transformation: Populism, community, and accelerated pluralism. https://doi.org/10.2307/3235370

Bimber, B. (1999). The Internet and citizen communication with government: Does the medium matter? Political Communication, 16, 409-428. https://doi.org/10.1080/105846099198569

Bimber, B. (2000). The study of information technology and civic engagement. Political Communication, 17, 329-333. https://doi.org/10.1080/10584600050178924

Blumler, J., \& Gurevitch, M. (2001). The new media and our political communication discontents: Democratizing cyberspace. Information Communication and Society, 4(1), 1-13. https://doi.org/10.1080/13691180122174 
Boczkowski, P. (2004). Digitizing the news: Innovation in online newspapers. MIT Press. https://doi.org/10.7551/mitpress/2435.001.0001

Bonsón, E., Torres, L., Royo, S., \& Flores, F. (2012). Local e-government 2.0: Social media and corporate transparency in municipalities. Government Information Quarterly, 29(2), 123-132. https://doi.org/10.1016/j.giq.2011.10.001

Brody, R. A. (1978). The puzzle of political participation in America. In A. King (Ed.), The new American political system (pp. 287-324). American Enterprise Institute.

Bucy, E. (2004). Second generation net news: Interactivity and information accessibility in the online environment. International Journal on Media Management, 6, 102-113. https://doi.org/10.1080/14241277.2004.9669386

Carpini, D. (2000). Gen.com: Youth, civic engagement, and the new information environment. Political Communication, 17, 341-349. https://doi.org/10.1080/10584600050178942

Carter, L., \& Belanger, F. (2004). Citizen adoption of e-government initiatives. https://doi.org/10.1109/HICSS.2004.1265306

Carter, L., \& Belanger, F. (2005). The utilization of e-government services: Citizen trust, innovation and acceptance factors. Information Systems Journal, 15, 5-25. https://doi.org/10.1111/j.13652575.2005.00183.x

Cassell, C. A., \& Luskin, R. C. (1988). Simple explanations of turnout decline. American Political Science Review, 82(4), 1321-1330. https://doi.org/10.2307/1961763

Chau, P. Y. K. (1996). An empirical assessment of a modified technology acceptance model. Journal of Management Information Systems, 13(2), 185-204. https://doi.org/10.1080/07421222.1996.11518128

CIRCLE (2003). The civic mission of schools. The Carnegie Corporation of New York.

Clift, S. L. (2004). E-government and democracy. Representation and citizen engagement in the information age, 40.

Coalition for Civic Engagement and Leadership. (2004). A working definition of civic engagement. www.nlu.nl.edu/cec/upload/Working-Definition-of-Civic-Engagement.pdf

Danziger, J. N., Dutton, W. H., Kling, R., \& Kraemer, K. L. (1982). Computers and politics: High technology in American local governments. Columbia University Press.

Davis, F. D. (1989). Perceived usefulness, perceived ease of use, and user acceptance of information technology. MIS Quarterly, 13, 319-339. https://doi.org/10.2307/249008

Delli Carpini, M. X. (2000). Gen.com: Youth, civic engagement, and the new information environment. Political Communication, 17, 341-349. https://doi.org/10.1080/10584600050178942

Dutta-Bergman, M. J. (2005). Access to the Internet in the Context of Community Participation and Community Satisfaction. New Media \& Society, 7(1), 89-109. https://doi.org/10.1177/1461444805049146

Dwivedi, Y. K., Rana, N. P., Tajvidi, M., Lal, B., Sahu, G. P., \& Gupta, A. (2017, March). Exploring the role of social media in e-government: an analysis of emerging literature. In Proceedings of the 10th international conference on theory and practice of electronic governance (pp. 97-106). https://doi.org/10.1145/3047273.3047374

Fishkin, J. S. (1991). Democracy and deliberation: New directions for democratic reform. Yale University Press.

Gutmann, A., \& Thompson, D. (1996). Democracy and disagreement. Harvard University Press.

Habermas, J. (1989). The structural transformation of the public sphere. MIT Press.

Habermas, J. (1992). Further reflections on the public sphere (T. Burger, Trans.). In C. Calhoun (Ed.), Herbamas and the public sphere. MIT Press.

Habermas, J. (1996). Between facts and norms: Contributions to a discourse theory of law and democracy (W. Rehg, Trans.). MIT Press. https://doi.org/10.7551/mitpress/1564.001.0001

Hacker, K. L., \& van Dijk, J. (Eds.) (2000). Digital democracy: Issues of theory and practice. Sage. https://doi.org/10.4135/9781446218891

Hand, L. C., \& Ching, B. D. (2011). "You have one friend request" An exploration of power and citizen engagement in local governments' use of social media. Administrative Theory \& Praxis, 33(3), 362-382. https://doi.org/10.2753/ATP1084-1806330303

Hasse, A. Q., Wellman, B., Witte, J., \& Hampton, K. N. (2002). Capitalizing on the Internet: Network capital, participatory capital and a sense of Community. In B. Wellman \& C. Haythornthwaite (Eds.), The Internet and everyday life (pp. 291-324). Blackwell. 
Hill, K. A., \& Hughes, J. E. (1998). Cyberpolitics: Citizen activism in the age of the Internet. Rowman \& Littlefield.

Hsu, M. K., Wang, S. W., \& Chiu, K. K. (2009). Computer attitude, statistics anxiety and self-efficacy on statistical software adoption behavior: An empirical study of online MBA learners. Computers in Human Behavior, 25, 412-420. https://doi.org/10.1016/j.chb.2008.10.003

Jaeger, P. T., \& Bertot, J. C. (2010). Transparency and technological change: Ensuring equal and sustained public access to government information. Government Information Quarterly, 27(4), 371-376. https://doi.org/10.1016/j.giq.2010.05.003

Jeffres, L. W., Atkin, D., \& Neuendorf, K. A. (2002). A model linking community activity and communication with political attitudes and involvement in neighborhoods. Political Communication, 19(4), 387-421. https://doi.org/10.1080/01957470290055574

Jennings, M. K., \& Zeitner, V. (2003). Internet use and civic engagement: A longitudinal analysis. Public Opinion Quarterly, 67(3), 311-334. https://doi.org/10.1086/376947

Johnson, T. J., \& Kaye, B. K. (1998). The Internet: Vehicle for engagement or a haven for the disaffected? In S. P. Hays (Ed.), Engaging the public: How the government and media can reinvigorate American democracy (pp. 123-135). Rowman \& Littlefield.

Johnson, T. J., \& Kaye, B. K. (2000). Democracy's rebirth or demise? The influence of the Internet on political attitude. In D. Schultz (Ed.), It's show time! Media, politics, and popular culture (pp. 209-228). Peter Lang.

Kaigo, M., \& Okura, S. (2017). Promotion and care of online communities: Necessary elements for a selfsustainable online Facebook community. In Social media and civil society in Japan (pp. 121-151). Palgrave Macmillan, Singapore. https://doi.org/10.1007/978-981-10-5095-4_5

Kang, S., \& Gearhart, S. (2010). E-government and civic engagement: How is citizens' use of city web sites related with civic involvement and political behaviors?. Journal of Broadcasting \& Electronic Media, 54(3), 443-462. https://doi.org/10.1080/08838151.2010.498847

Kavanaugh, A. L., \& Patterson, S. J. (2001). The impact of community computer networks on social capital and community involvement. American Behavioral Scientist, 45(3), 469-509. https://doi.org/10.1177/00027640121957312

Keeter, S., Zukin, C., Andolina, M., \& Jenkins, K. (2002). The civic and political health of the nation: A generational portrait (Report). CIRCLE.

Kent Jennings, M., \& Zeitner, V. (2003). Internet use and civic engagement: A longitudinal analysis. Public Opinion Quarterly, 67(3), 311-334. https://doi.org/10.1086/376947

Kim, Y. C. (2003). Storytelling community: Communication infrastructure and civic engagement in Urban Spaces (Unpublished dissertation), University of Southern California, Los Angeles.

Kim, Y. C., \& Ball-Rokeach, S. J. (2006). Civic engagement from a communication infrastructure perspective. Communication Theory, 26, 173-197. https://doi.org/10.1111/j.1468-2885.2006.00267.x

Kinder, D. R. (2002). Pale democracy: Opinion and action in post-war America. In E. D. Mansfield, \& R. Sisson (Eds.), The evolution of political knowledge: Theory and inquiry in American politics (pp. 104-162). Ohio State University Press.

King, S., \& Cotterill, S. (2007). Transformational government? The role of information technology in delivering citizen-centric local public services. Local Government Studies, 33(3), 333-354. https://doi.org/10.1080/03003930701289430

Krippendorff, K. (2009). The content analysis reader. Sage.

Kwak, N., Williams, A., Wang, X., \& Lee, H. (2005). Talking politics and engaging politics: An examination of the interactive relationships between structural features of political talk and discussion engagement. Communication Research, 32(1), 87-111. https://doi.org/10.1177/0093650204271400

Lederer, A. L., Maupin, D. J., Sena, M. P., \& Zhuang, Y. (2000). The technology acceptance model and the World Wide Web. Decision Support Systems, 29, 269-282. https://doi.org/10.1016/S0167-9236(00)00076-2

Lee, G., \& Kwak, Y. H. (2012). An open government maturity model for social media-based public engagement. Government Information Quarterly, 29(4), 492-503. https://doi.org/10.1016/j.giq.2012.06.001

Lee, J. (2010). 10 year retrospect on stage models of e-government: A qualitative meta-synthesis. Government Information Quarterly, 27(3), 220-230. https://doi.org/10.1016/j.giq.2009.12.009

Lidén, G., \& Larsson, A. O. (2016). From 1.0 to 2.0: Swedish municipalities online. Journal of Information Technology \& Politics, 13(4), 339-351. https://doi.org/10.1080/19331681.2016.1169242 
Lin, F., Fofanah, S. S., \& Liang, D. (2011). Assessing citizen adoption of e-Government initiatives in Gambia: A validation of the technology acceptance model in information systems success. Government Information Quarterly, 28(2), 271-279. https://doi.org/10.1016/j.giq.2010.09.004

Lin, W. Y., \& Dutton, W. H. (2003). The 'Net' effect in politics: The 'Stop the overlay' Campaign in Los Angeles. Party Politics, 9(1), 124-136. https://doi.org/10.1177/1354068803009001723

Linders, D. (2012). From e-government to we-government: Defining a typology for citizen coproduction in the age of social media. Government Information Quarterly, 29(4), 446-454. https://doi.org/10.1016/j.giq.2012.06.003

Margolis, M., Resnick, D., \& Resnick, D. M. (2000). Politics as usual (Vol. 6). Sage.

McDermott, P. (2010). Building open government. Government Information Quarterly, 27(4), 401-413. https://doi.org/10.1016/j.giq.2010.07.002

McLeod, J. M., Daily, K., Guo, Z., Eveland, W., Bayer, J., Yang, S., \& Wang, H. (1996). Community integration, local media use and democratic processes. Communication Research, 23(2), 179-209. https://doi.org/10.1177/009365096023002002

McLeod, J. M., Scheufele, D. A., \& Moy, P. (1999). Community, communication, and participation: The role of mass media and interpersonal discussion in local political participation. Political Communication, 16(3), 315-336. https://doi.org/10.1080/105846099198659

McMillan, S. J., Hwang, J. S., \& Lee, G. (2003). Effects of structural and perceptual factors on attitudes toward the Website. Journal of Advertising Research, 43(4), 400-409. https://doi.org/10.2501/JAR-43-4-400-409

Miller, W. E. (1992). The puzzle transformed: Explaining declining turnout. Political Behavior, 14(1), 1- 43. https://doi.org/10.1007/BF00993507

Mossberger, K., Tolbert, C. J., \& McNeal, R. S. (2008). Digital citizenship: the internet. Society and Participation. https://doi.org/10.7551/mitpress/7428.001.0001

Moy, P., Manosevitch, E., Stamm, K., \& Dunsmore, K. (2005). Linking dimensions of Internet use and civic engagement. Journalism \& Mass Communication Quarterly, 82(3), 571-586. https://doi.org/10.1177/107769900508200306

Musso, J. Weare, C., \& Hale, M. (2001). Designing web technologies for local governance reform: Good management or good democracy? Political Communication, 17, 1-19. https://doi.org/10.1080/105846000198486

Mutz, D. (2002). Cross-cutting social networks: Testing democratic theory in practice. American Political Science Review, 96(1), 111-126. https://doi.org/10.1017/S0003055402004264

Mutz, D., \& Martin, P. (2001). Facilitating communication across lines of political difference: The role of mass media. American Political Science Review, 95(1), 97-114. https://doi.org/10.1017/S0003055401000223

Mwangi, S. C., Smethers, J. S., \& Bressers, B. (2014). If you build it, will they come? An exploratory study of community reactions to an open source media project in Greensburg, Kansas. Community Journalism, 3(1), 72-86.

Nam, T. (2012). Suggesting frameworks of citizen-sourcing via Government 2.0. Government Information Quarterly, 29(1), 12-20. https://doi.org/10.1016/j.giq.2011.07.005

Nielsen, J. (2005). Usability of Websites for teenagers. Alertbox: Current issues in usability research. http://www.useit.com/alertbox/20050131.html

Nip, J. Y. M. (2006). Exploring the second phase of public journalism. Journalism Studies, 7(2), 212-236. https://doi.org/10.1080/14616700500533528

Norris, P. (2000). A virtuous circle: Political communications in postindustrial societies. Cambridge University Press. https://doi.org/10.1017/CBO9780511609343

Oblak, T. (2005). The lack of interactivity and hypertextuality in online media. Gazette: International Journal for Communication Studies, 67, 87-106. https://doi.org/10.1177/0016549205049180

Okura, S., \& Kaigo, M. (2017). Japanese local government Facebook profiles. In Social media and civil society in Japan (pp. 73-96). Palgrave Macmillan, Singapore. https://doi.org/10.1007/978-981-10-5095-4_3

Paek, H. J., Yoon, S. H., \& Shah, D. V. (2005). Local news, social integration, and community participation: Hierarchical linear modeling of contextual and cross-level effects. Journalism \& Mass Communication Quarterly, 82, 587-606. https://doi.org/10.1177/107769900508200307

Papacharissi, Z. (2004). Democracy online: Civility, politeness and the democratic potential of online political discussion groups. New Media \& Society, 6(2), 259-283. https://doi.org/10.1177/1461444804041444 
Paquette, S., Jaeger, P. T., \& Wilson, S. C. (2010). Identifying the security risks associated with governmental use of cloud computing. Government Information Quarterly, 27(3), 245-253. https://doi.org/10.1016/j.giq.2010.01.002

Pinkleton, B., \& Austin, E. W. (1998). Media and participation: Breaking the spiral of disaffection. In S. P. Hays (Ed.), Engaging the public: How the government and media can reinvigorate American democracy (pp. 75-86). Rowman \& Littlefield.

Polat, R. K. (2005). The Internet and political participation. European Journal of Communication, 20(4), 435-459. https://doi.org/10.1177/0267323105058251

Pratte, R. (1988). The civic imperative. Teachers College Press.

Putnam, R. D. (1993). Making democracy work: Civic traditions in modern Italy. Princeton University Press. https://doi.org/10.1515/9781400820740

Putnam, R. D. (2000). Bowling alone: The collapse and revival of American community. Touchstone. https://doi.org/10.1145/358916.361990

Rose, W. R., \& Grant, G. G. (2010). Critical issues pertaining to the planning and implementation of EGovernment initiatives. Government Information Quarterly, 27(1), 26-33. https://doi.org/10.1016/j.giq.2009.06.002

Rosenberry, J. (2005). Few papers use online techniques to improve public communication. Newspaper Research Journal, 26(4), 61-73. https://doi.org/10.1177/073953290502600406

Schultz, T. (1999). Interactive options in online journalism: A content analysis of 100 US newspapers. Journal of Computer Mediated Communication, 5(1). https://doi.org/10.1111/j.1083-6101.1999.tb00331.x

Scott, J. K. (2006). "E” the People: Do U.S Municipal Government Websites Support Public Involvement?. Public Administration Review, 66(3), 341-353. https://doi.org/10.1111/j.1540-6210.2006.00593.x

Scott, W. (1955). Reliability of content analysis: The case of nominal scale coding. Public Opinion Quarterly, 17, 321-325. https://doi.org/10.1086/266577

Shah, D. V., McLeod, J. M., \& Yoon, S.-H. H. (2001). Communication, context, and community: An exploration of print, broadcast and Internet influences. Communication Research, 28(4), 464-506. https://doi.org/10.1177/009365001028004005

Shah, S., Cho, J., Eveland, W. P., \& Kwak, N. (2005). Information and expression in a digital age: Modeling Internet effects on civic participation. Communication Research, 32(5), 531-565. https://doi.org/10.1177/0093650205279209

Shareef, M. A., Kumar, V., Kumar, U., \& Dwivedi, Y. K. (2011). e-Government Adoption Model (GAM): Differing service maturity levels. Government Information Quarterly, 28(1), 17-35. https://doi.org/10.1016/j.giq.2010.05.006

Swanson, D. L. (2000). The homologous evolution of political communication and civic engagement: Good news, bad news, and no news. Political Communication, 17, 409-414. https://doi.org/10.1080/10584600050179031

Tambini, D. (1999). New media and democracy: The civic networking movement. New Media \& Society, 1(3), 305-329. https://doi.org/10.1177/14614449922225609

Van der Heijden, H. (2003). Factors influencing the usage of websites: The case of a generic portal in the Netherlands. Information and Management, 40(6), 541-549. https://doi.org/10.1016/S03787206(02)00079-4

Verba, S., \& Nie, H. (1972). Participation in America: Political democracy and social equality. University of Chicago Press.

Verba, S., Schlozman, K. L., \& Brady, H. F. (1995). Voice and equality: Civic voluntarism in American politics. Harvard University Press. https://doi.org/10.2307/j.ctv1 pnc1k7

Wang, Y. S. (2002). The adoption of electronic tax filing systems: An empirical study. Government Information Quarterly, 20, 333-352. https://doi.org/10.1016/j.giq.2003.08.005

Weare, C. (2000, August 1-5). Technology and politics: Linking the Internet to changes in democratic governance [Paper presentation]. The Internet Conference at the International Political Science World Congress, Quebec City.

Wellman, B., Haase, A. Q., Witte, J., \& Hampton, K. (2001). Does the Internet increase, decrease, or supplement social capital? Social networks, participation, and community commitment. American Behavioral Scientist, 45(3), 436-455. https://doi.org/10.1177/00027640121957286 
Wild, A., \& Marshall, R. (1999). Participatory practice in the context of Local Agenda 21: A case study evaluation of experience in three English local authorities. Sustainable Development, 7(3), 151-162. https://doi.org/10.1002/(SICI)1099-1719(199908)7:3<151::AID-SD111>3.0.CO;2-0

Wimmer, R. D., \& Dominick, J. R. (1997). Mass media research: An introduction. Cengage Learning.

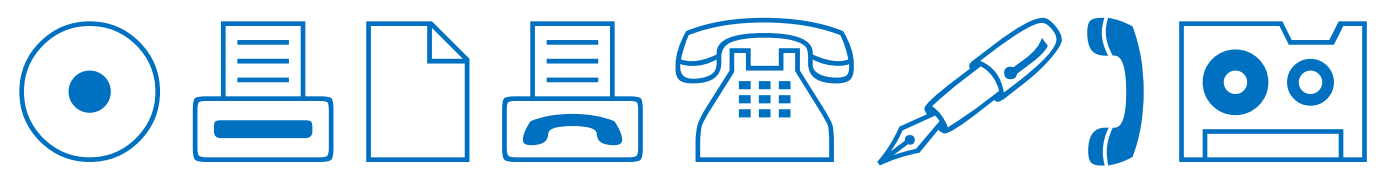

